Access to Justice in Eastern Europe,

Issue 1 (6) 2020 10.33327/AJEE-18-3.1

ISSN 2663-0575 (Print)

ISSN 2663-0583 (Online)

http://ajee-journal.com

T Zoroska Kamilovska 'Privatization of Civil Justice: Is it Undermining or Promoting the Rule of Law?' (2020) 1(6) Access to Justice in Eastern Europe 34-45. 10.33327/AJEE-18-3.1-a000027

Received 10.01.2019

Revised 20.01.2019

Approved 22.01.2019

\title{
PRIVATIZATION OF CIVIL JUSTICE: IS IT UNDERMINING OR PROMOTING THE RULE OF LAW?
}

\author{
Dr. Tatjana Zoroska Kamilovska \\ Professor of Civil Procedure \\ Ss. Cyril and Methodius University in Skopje \\ Faculty of Law 'Iustinianus Primus', North Macedonia
}

Doi 10.33327/AJEE-18-3.1-a000027

Summary: 1. Introduction. - 2. Privatization of civil justice. - 3. The Rule of Law concept. - 4. Does Privatized Justice Undermine or Promote the Rule of Law? 5. Concluding Remarks.

The crisis of civil justice system is present in many countries in the EU and worldwide and it takes different forms. In response, many different pathways are explored in order to overcome not only the growing sense of crisis, but also its manifestations. One of the suggested routes in the ongoing efforts to improve access to civil justice at the EU and national levels is the privatization of justice through the ADR mechanisms. In many areas, with the encouragement and support of governments and other policy-making bodies, the administration of justice is being encouraged to leave the courts for alternative forums. Thereby, the ADR are presented as mechanisms which are facilitating informal, fast, costeffective and affordable access to justice, at the same time preserving public resources. Yet, 
in spite of these undeniable benefits, ADR mechanisms are subject of some doubts and expressed concerns.

One of the major concerns, which has already sparked a wider debate, is whether the informal and private nature of ADR is hostile to the Rule of Law and ultimately to justice itself. Namely, if the privatization of civil justice is considered in the context of the fundamental public commitment to provide substantive justice on an equal basis to all citizens, the question arises whether the ADR mechanisms are capable to secure and foster the virtues of the Rule of Law (publicity, transparency, fairness, equality, etc.).

The purpose of this paper is to contribute to this debate, renewing the interest in analyzing the relationship between the privatization of civil justice and the concept of the Rule of Law. In the light of evolving social, economic and political circumstances, the paper attempts to answer the question whether the growing privatized dispute resolution landscape is undermining or promoting the rule of law.

Key words: crisis of civil justice system, privatization of civil justice, rule of law

\section{INTRODUCTION}

Back in 1999 professor Zuckerman started his widely known collection of essays by assertion that:

'There is a widespread perception that the administration of civil justice is failing to meet the needs of the community. This perception seems to persist across national and cultural frontiers. It is present in many different countries, both within the common law and civil law legal systems. Access to justice is so adversely affected by high litigation costs and long delays that in quite a few countries the courts no longer provide an adequate venue for seeking the protection of rights or for resolving disputes. It is no exaggeration to say that many systems of civil justice experience a crisis of some kind'. ${ }^{1}$

Two decades later, it seems that nothing has changed. Zuckerman's words still sound fresh and more or less they describe the state of affairs of civil justice in many national justice systems in the first two decades of $21^{\text {st }}$ century. As professor Marcus concluded in his research paper on the same subject matter 'happy days are not here yet'. ${ }^{2} \mathrm{~A}$ number of factors over the last decade have created a situation in which the value of civil justice is being undermined and the civil courts are in the state of dilapidation. ${ }^{3}$

Although citizens and businesses need to be assured that, as a final resort, they can seek legal protection from the courts in a reasonable time, according to consistent standards and without any outside interference in the process of adjudication, many national justice systems are still struggling delays, inefficiencies, increased caseloads, excessive

\footnotetext{
1 See preface of AAS Zuckerman (ed), Civil Justice in Crisis (Oxford UP 1999).

2 Richard Marcus, 'A Genuine Civil Justice Crisis?' (March 21, 2017) XV International Association of Procedural Law World Congress 27 (2015); UC Hastings Research Paper No. 238, $32<\mathrm{https}$ ://ssrn.com/ abstract $=2938793>$ accessed 10 December 2019.

3 See Hazel Genn, Judging Civil Justice (Cambridge UP 2009).
} 
costs and interference of different kinds. ${ }^{4}$ Therefore, instead of creating a climate of certainty and reliability (particularly by guaranteeing the security of property rights and the enforcement of contracts) and thus generating a certain degree of trust and public confidence, the judiciary in many countries is facing long-term dissatisfaction. The expectations of the citizens to live and the business to be done under a system that operates within the Rule of Law have not been fulfilled yet.

In response to this crisis, many different pathways are explored in order to overcome not only the growing sense of crisis, but also its manifestations. One of the suggested routes, rapidly and increasingly occurring at all levels of the public justice system, is the privatization of civil justice through the alternative dispute resolution mechanisms (shorthand phrase 'ADR'). ${ }^{5}$ This route is driven by a wide spread ethos of efficiencybased civil justice reform, ${ }^{6}$ as the efficiency has become the underlying principle in many justice reform initiatives.

As the title of this paper suggests, it is about the privatization of civil justice and its potential implications for the Rule of Law. At the beginning of the paper we will briefly present the essence of two concepts at stake: the privatization of civil justice and the Rule of Law and then we will link them and try to find out to which extent the first influences the second.

\section{THE PRIVATIZATION OF CIVIL JUSTICE CONCEPT}

The phenomenon of privatization of civil justice ${ }^{7}$ is well known, but still for the purposes of this paper a definitional framework of it is needed. Let us very concisely sketch its essence.

Broadly defined, the civil justice system is nothing - but substantive law, machinery and procedure for vindication and defending civil claims - in effect the entire system of civil justice in civil matters. ${ }^{8}$ Traditionally, civil justice is considered as a function of the public realm, which enables private parties to invoke the power of state dispensed in the judiciary to resolve private disputes according to law and then to enforce the public

$4 \quad$ An extensive body of legal and empirical studies confirms this reality. See for example 'European Judicial Systems, Efficiency and quality of justice', CEPEJ Studies No. 26, 2018 Edition (2016 data).

5 Some studies suggest an increasing trend towards defining ADR as 'appropriate' rather than 'alternative' dispute resolution. See Access to Justice Literature Review: Alternative Dispute Resolution in Scotland and other jurisdiction (2014), Scottish Civil Justice Council https://www.scottishciviljusticecouncil.gov. $\mathrm{uk} /$ docs/librariesprovider4/scjc-pubilcations/literature-review-on-adr-methods.pdf?sfvrsn=2 accessed 10 December 2019.

6 See Trevor CW Farrow, Civil Justice, Privatization and Democracy (University of Toronto Press 2014).

7 Besides the terms privatization, privatizing, privatized, the terms outsourcing, outsourced are used for describing the same phenomenon. Sometimes the slight difference between them is emphasized. For example, Tracy W. McCormack starts her article with the question: 'What does it mean when we say our justice system has been privatized or outsourced?' And further she says: 'If one distinguishes between the two phrases, then in the extreme view, it is justice outsourced; in a milder form, it is the privatization of the justice system.' See Tracy W McCormack, 'Privatizing the Justice System' (2006) 25 Review of Litigation 735 .

8 Sir Jack Jacob, The Fabric of English Civil Justice (Sweet \& Maxwell 1987) 1-2. Moreover, he says that the ambit of civil justice is wide and far-reaching and its bounds have not yet been fully chartered; it encompasses the whole area of what is comprised in civil procedural law. 
decision by public force. ${ }^{9}$ This marks the state courts or the judiciary as the primary public venues in which citizens resolve their disputes. Contrariwise, privatization of civil justice means that large elements of the states' civil justice regime are shifting away from the public realm towards a wide range of private dispute resolution services and processes. In short, the phenomenon refers to a shift to private ownership and control of civil justice services. The most frequently invoked label that highlights this private system of dispute resolution is ADR. ADR refers to private mechanisms of resolving disputes outside of the court processes, allowing parties to tailor-make their process in order to incorporate the needs of both parties. It has become the leading trend in resolving disputes during the course of the last few decades.

In the light of such a development, a new thesis has been set that the 'public route' to judgment or the court litigation must be regarded as a matter of 'last resort.'10 On the other side, it is also true that the processes (meaning public one) of civil justice have never been regarded as an option of 'first resort' in terms of dispute resolution. ${ }^{11}$ Frances Kellor has duly noted that historically speaking:

'Of all mankind's adventure in search of peace and justice, arbitration is among the earliest. Long ago the law was established, or courts were organized, or judges had formulated the principles of law, men had resorted to arbitration for the resolving of discord, the adjustment of differences, and the settlement of disputes.12

But, even after the law was established and the courts were organized, parties have always been encouraged to resolve their disputes informally before resorting to litigation. Traditionally, issues that reach the stage of public formal civil litigation are, by definition, issues that parties have not been able to resolve informally among themselves. ${ }^{13}$ Thus, the novelty in a modern era of dispute resolution is that ADR has gained a default position: ADR takes on the attributes of adjudication; it becomes the means for enabling 'access to justice' when adjudication fails. ${ }^{14}$

Although the ADR roster is complex and rich in terms of methods, which enables a lengthy discussion of distinctions among processes called arbitration, court-annexed arbitration, conciliation, mediation, med-arb, mini-trial, early neutral evaluation, judicial settlement conferences etc., ${ }^{15}$ we will not detail its entire array here. As professor Resnik writes: 'My interest here is in the relationship of ADR in its generic form, as an idea of an alternative regime to state-based adjudication ${ }^{16}$ and its prevalence over public justice system.

9 Peter L. Murray, 'Privatization of civil justice' (2007) 15(2) Willamette Journal of International Law and Dispute Resolution, 134.

10 Neil Andrews, The Modern Civil Process: Judicial and Alternative Forms of Dispute Resolution in England (Mohr Siebeck 2008) 7-8.

11 Murray (n 9) 134.

12 Frances A Kellor, American Arbitration: Its History, Functions and Achievements (reprinted Beard Books 2000) 3.

13 Murray (n 9) 135.

14 Judith Resnik, 'Many Doors? Closing Doors? Alternative Dispute Resolution and Adjudication (1995) 10 (2) The Ohio State Journal on Dispute Resolution 245.

15 For comprehensive descriptions of ADR methods, see Susan Blake, Julie Browne \& Stuart Sime, A Practical Approach to Alternative Dispute Resolution ( $5^{\text {th }}$ edn Oxford UP 2018).

16 Resnik (n 14) 222. 
Indisputably, the success of the private dispute resolution services and processes is a reflection of the shortcomings of the contemporary civil justice system, briefly explained above. From that perspective, there are many sound rationales for this privatization trend or movement, including reduced costs, increased speed and efficiency, privacy, enhanced participation and autonomy through increased party choice within and control over dispute resolution processes and improved access to the tools of justice. ${ }^{17}$ Therefore, in many areas (such as commercial, consumer, family matters etc.), with the encouragement and support of governments and other policy-making bodies, the administration of justice is being encouraged to leave the courts for alternative forums. 18 Thereby, the ADR are presented as mechanisms which are facilitating informal, fast, cost-effective and affordable access to justice, while at the same time preserving public resources. Generally, it is said that ADR enjoys an advantage over court-based dispute resolution processes in speed and effectiveness, without compromising parties' expectations of fairness and without compromising the parties' ultimate rights to access the state justice system. Additionally, as ADR mechanisms generally lead to an agreed solution, they contribute quietly to social and economic well-being and promote social harmony. ${ }^{19}$ In a nutshell and to be more poetic, in favor of ADR it is said that many parties may regret a case they contest, but few will regret a case they settle.

For these reasons, ADR mechanisms are developing progressively, but at different speeds and directions in different parts of Europe $\mathrm{e}^{20} 21$ and worldwide. It should not be neglected that in many countries, there is a great cultural and economic resistance to the promotion and use of ADR. Indeed, many countries so far are facing the failure to make ADR familiar to the public and culturally normal. But even in these circumstances, ADR is present and has become a 'quiet constant' with perspective, something that persists and waits for the time to flourish. It seems that meeting this challenge will ultimately be more important than any tuning of the rules of civil procedure on the way of building an effective civil justice system.

17 See Farrow (n 6) 7-8.

18 The encouragement and support of governments and other policy-making bodies is necessary since the private alternative dispute resolution relies on the coercive power of the state.

19 The significance of ADR not only as a legal but also as a social value is emphasized in Green paper on alternative dispute resolution in civil and commercial law, Commission of the European Communities, (2002) Item 10, Chapter 1.2.

20 See for example, Alternative Dispute Resolution and Judicial Domain, ENCJ Report 2016/2017; Christopher Hodges, Iris Benöhr, Naomi Creutzfeldt, Consumer ADR in Europe (Hart Pub 2012). In the recent study on the development in consumer ADR in Europe, among its principal findings, the following can be read: 'There is a clear division between EU Member States that have sophisticated CDR schemes - and, despite the differences between States, are improving their mechanisms - and those States that have very undeveloped Consumer Dispute Resolution (CDR provision). The national landscapes of ADR bodies continue to present problems, notably lack of full coverage and low consumer confidence in the current system.' See Christopher Hodges, Developments and Issues in Consumer ADR and Consumer Ombudsman in Europe (FLJS 2019) 1.

21 Besides national developments, the developments at the European level should also be mentioned. There are currently three main ADR instruments in force in the European Union: Directive 2008/52/EC of the European Parliament and of the Council of 21 May 2008 on certain aspects of mediation in civil and commercial matters, OJ L 136, 24.5.2008, Directive 2013/11/EU of the European Parliament and of the Council of 21 May 2013 on alternative dispute resolution for consumer disputes and amending Regulation (EC) No 2006/2004 and Directive 2009/22/EC, OJ L 165, 18.6.2013 and Regulation (EU) No $524 / 2013$ of the European Parliament and of the Council of 21 May 2013 on online dispute resolution for consumer disputes and amending Regulation (EC) No 2006/2004 and Directive 2009/22/EC OJ L $165,18.6 .2013$. 


\section{THE RULE OF LAW CONCEPT}

Let's now turn to the second key concept at stake: the Rule of Law. Namely, as the dispute resolution system is increasingly privatized, the possible implications this might hold for the Rule of Law and for justice itself, should not be ignored. Of course, the question is: why?

Many assume (very reasonably) that this might be a very odd question, since ADR is often included as a part of Rule of Law projects whereas ADR and litigation approaches usually go hand in hand. ${ }^{22}$ In these projects, the availability of ADR mechanisms to complement court structures aims to promote access to justice for individuals and businesses. And nobody objects that ADR is promoting the access to justice, which is an essential element of the Rule of Law. But, it's only one element: the Rule of Law is multi-faceted and dynamic concept, which is comprised of many other things. Considering this, several questions arise: What about the other elements of the concept? Are they eroded by these ADR mechanisms? Or is ADR promoting the Rule of Law? In order to answer these questions, allow us to put forward few words about the definition of the Rule of Law concept and its key elements. In this respect, our intention here is not to write extensively on a concept that has been discussed for decades if not centuries, but just to put some underpinnings for the following discussion.

As usual, there is a multiplicity of definitions and understandings of the Rule of Law concept in legal theory and philosophy. The multiplicity derives from the dilemma which elements to include in the concept. Most definitions however 'give central place to a requirement that people in positions of authority should exercise their power within a constraining framework of public norms, rather than on the basis of their own preferences, their own ideology, or their own individual sense of right and wrong. ${ }^{23}$ Or to put it differently, the Rule of Law centrally comprises 'the values of regularity and restraint, embodied in the slogan of "a government of laws, not men"'. ${ }^{24}$ This slogan indeed means that the law is absolutely supreme and it excludes the arbitrariness in any form, a point that might be very important in the context of discussion on privatization of civil justice. At the same time, the slogan puts emphasis on the legal certainty, predictability, and the determination of the norms that are upheld in society and the reliable character of their administration by the state. ${ }^{25}$

Even this brief elaboration of what the definition of the Rule of Law entails, brings us to the key elements of the concept. More or less, there is an overlapping consensus about certain elements of the concept that virtually everyone would agree upon. Most scholars however provide for a non-exhaustive list of elements of the concept, which includes, but is not limited to: legality, legal certainty, non-arbitrary exercise of power, equality

22 See Jean R Sternlight, 'Is Alternative Dispute Resolution Consistent with the Rule of Law?: Lessons from Abroad (2007) 56 DePaul L Rev 581.

23 Jeremy Waldron, 'The Concept and the Rule Law (2008) 43(1) Georgia Law Review 6.

24 Allan C Hutchinson and Patrick J Monahan, The Rule of Law: Ideal or Ideology (Toronto: Carswell, 1987) ix.

25 Waldron (n 23) 6. 
before the law, access to justice, effective judicial review, independent and impartial courts, etc. ${ }^{26}$

Each element has its own significance for maintaining the concept, but for the question we raised in this paper, doubtlessly, the judiciary is indispensable to the Rule of Law. The judiciary or public justice system plays a crucial role in upholding the Rule of Law and the adjudicative process is the main lever of the Rule of Law. The adjudicative process, at least in general terms, provides an authoritative statement of what the law is, who has what rights, and how these rights have to be vindicated. ${ }^{27}$ It provides the idea of formal predictability and legality and promotes individual autonomy in the way of allowing people to live in certainty.

The adjudicative process itself is governed by some principles, which are treated as specific procedural aspects of the Rule of Law concept. Namely, more inclusive Rule of Law definitions incorporate some procedural issues or safeguards besides the formal side of the ideal. As Waldron explains:

'A procedural understanding of the Rule of Law requires not only that officials apply the rules as they are set out; it requires the application of the rules with all the care and attention to fairness that is signaled by ideals such as 'natural justice and 'procedural due process. Thus, if someone is accused of violating one of the general norms laid down, they should have an opportunity to request a hearing, make an argument, and confront the evidence before them prior to the application of any sanction associated with the norm.28

The mentioned 'procedural due process stipulates certain principles of process by which the laws that are publicly made and promulgated shall be administered by the courts (for example fairness, equality, publicity, transparency etc.). Instead of the certainty guaranteed by proper application of general norms which makes private freedom possible, the procedural aspects of the Rule of Law seem to value opportunities for active engagement in the administration of justice. Basically, these two currents of thought of the Rule of Law concept - the first puts the emphasis on formal legality and the second pays attention to procedural due process - sit comfortably together and complement each other. The two considerations taken together make the notion of the Rule of Law a most powerful and profound political ideal in contemporary global discourse.

\section{DOES PRIVATIZED JUSTICE UNDERMINE OR PROMOTE THE RULE OF LAW?}

We have previously concluded that judiciary and adjudicative processes, though crucial for upholding the Rule of Law, are not sufficient to capture the needs of a modern

$26 \quad$ See, for example, Geranne Lautenbach, The Concept of the Rule of Law and the European Court of Human Rights (Oxford UP 2014) and Rafael Leal-Arcas, 'Essential Elements of the Rule of Law Concept in the EU (2014) Queen Mary University of London, School of Law Legal Studies Research Paper No. 180/2014 https://ssrn.com/abstract=2483749 assessed 10 December 2019.

Genn (n 3) 320. In the same direction, Alexandra D Lahav writes that: 'Adjudication is usually understood as having two functions: dispute resolution and law declaration, The Roles of Litigation in American Democracy (2016) Emory Law Journal 1657.

Waldron (n 23) 7-8. 
system of disputes resolution and they are complemented by alternative forums. In this constellation, as was mentioned previously, the following question arises: do these alternative forums (or ADR mechanisms) have the same capacity to uphold the mentioned virtues of the Rule of Law or do they erode the vitality of the Rule of Law that the public justice system tries to maintain?

The question raised is neither new nor definitely answered. For a while now, along with the proliferation of ADR mechanisms a debate on whether the informal and private nature of ADR is hostile to the Rule of Law and ultimately to justice itself is going on. ${ }^{29}$ We can also very often read the articles posing the question: Do ADR deliver justice $?^{30}$ Having spent time over the past few months reading the considerable body of literature on this topic, our general impression is that most scholars and sometimes even practitioners argue that ADR and the Rule of Law seem fundamentally incompatible. ${ }^{31}$ Many aspects are emphasized in favour of that incompatibility. We tried to pull together viewpoints and concerns from various sources to provide some context of the debate.

To begin with, it is said that the Rule of Law seeks to resolve disputes according to legal rules established by the state, while ADR (with the possible exception of arbitration) looks to resolve disputes largely by reference to non-law standards, such as underlying interests and preferences of the parties. ${ }^{32}$ Namely, although the major goal of ADR processes is the same as litigation, i.e. dispute resolution, the important distinction is that $\mathrm{ADR}$ focuses on the interests of the parties rather than their legal rights, in that way its goal is to resolve the dispute so that the full interests of each party are satisfied. Therefore, more and more disputes are settled regarding the disputant's individual preferences and interests, rather than resolved according to the law. But, some scholars think that this might be unfair. They notably criticized the use of ADR (more precisely

29 See for example Sternlight (n 22), Trevor CW Farrow, 'Privatizing our Public Civil Justice System (2006) Articles \& Book Chapters Paper 1930, http://digitalcommons.osgoode.yorku.ca/scholarly_works/1930 accessed 10 December 2019, Hazel Genn, 'Why the Privatisation of Civil Justice is a Rule of Law Issue (2012) 36th F A Mann Lecture, Lincoln's Inn, 19 November 2012 https://www.ucl.ac.uk/laws/sites/laws/ files/36th-f-a-mann-lecture-19.11.12-professor-hazel-genn.pdf accessed 10 December 2019, Mediation and the Rule of Law, Keynote of Address by the Honourable the Chief Justice Sundaresh Menon, Supreme Court of Singapore, The Law Society Mediation Forum Singapore, 10 March $2017<\mathrm{https} / /$ www.supremecourt.gov.sg/Data/Editor/Documents/Keynote\%20Address\%20-\%20Mediation\%20 and\%20the\%20Rule\%20of\%20Law\%20(Final\%20edition\%20after\%20delivery\%20-\%20090317).pdf accessed 10 December 2019.

30 Sherif Elnegahy, 'Can Mediation Deliver Justice? (2017) 18 Cardozo Journal of Conflict Resolution, Anna Nylund, 'Access to Justice: Is ADR a Help or Hindrance? in Laura Ervo, Anna Nylund (eds), The Future of Civil Litigation - Access to Courts and Court-annexed Mediation in the Nordic Countries (Springer, Cham 2014).

31 Of course, there are many different viewpoints, sometimes based on scope of definition of the Rule of Law concept. For example Jean R Sternlight (n 22), 590, argues that 'the question of whether ADR and the rule of law are consistent is semantic. If the rule of law is narrowly defined only to include litigationoriented approaches, then most ADR processes are inconsistent with the rule of law. If, on the other hand, the rule of law is more broadly defined, as it sometimes has been in the international context, then rule of law projects may include ADR elements. To the extent the discussion remains on this purely semantic level, it is not particularly interesting.'

32 In the same way Harry T Edwards, 'Commentary, Alternative Dispute Resolution: Panacea or Anathema?(1986) 99 (3) Harvard Law Review 668, cautions that 'a virtue of adjudication is its ability to ensure the proper resolution and application of public values, and that public officials, not private individuals, must interpret the values of the Constitution and statutes.' 
mediation) on the grounds that it might not appear fair to some disputants, because it did not promote a resolution based on public norms. ${ }^{33}$

Then comes the very often mentioned paradox of privatizing the justice at a time when law is apparently proliferating - reaching into every aspect of business, private and public life ${ }^{34}$ in order to provide legal certainty and ensure that the law rules, not the people. In the same context, it is argued that 'in the privatized world of justice resolution you may have the law, but it does not rule. You may not even have the law and certainly you do not have the values of the public justice system.' ${ }^{35}$

In addition to this, publicity is pointed out as crucial for justice and the Rule of Law in terms of keeping the judiciary under scrutiny. The protagonists of the mentioned incompatibility very often refer to the citation of famous Jeremy Bentham's saying: 'Where there is no publicity there is no justice. Publicity is the very soul of justice.' Therefore, it is obvious that when privatizing significant sections of the adjudicative function, making them private and confidential, we are 'systematically and knowingly treading on the key rules of legal protections. ${ }^{36}$ It is said:

'There is the point that ADR processes are essentially private, involving only the parties, their lawyers and any third parties they choose to bring in. This privacy may be a major attraction for the parties, but justice is traditionally done in open court, and there are questions as to whether justice will always be done in private proceedings. ${ }^{37}$

Moreover, it is suggested that court proceedings are governed by well-developed due process values. Public judgment is reached at the end of hearings which provide formal, tightly structured opportunities for an impartial decision-maker to determine the rights and responsibilities of particular persons fairly and effectively, after hearing evidence and arguments from both sides. ${ }^{38}$ Contrariwise, 'privatized dispute resolution processes (with the possible exception of arbitration) do not have this commitment to process. Without scrutiny it is impossible to know whether the processes or the outcomes for parties are fair in the context of the legal rights and responsibilities that gave rise to the dispute. ${ }^{39}$

33 Deborah Hensler, 'Suppose It's Not True: Challenging Mediation Ideology' (2002) Journal of Dispute Resolution 95. She points out that 'the question of whether (and when) people prefer dispute resolution based on public legal norms to dispute resolution based on ad hoc privately negotiated norms unfortunately has not been subjected to much investigation to date.' However, she thinks that 'the legitimacy that people accord the courts - which is essential to a rule of law - is dependent on the courts offering the opportunity to resolve disputes on the basis of facts and law, using fair, thorough, and dignified procedures, to all who seek it.'

34 Genn (n 29) 2.

35 Genn (n 29) 20.

36 Farrow (n 5) 37.

37 Susan Blake, 'The Contractual Basis for ADR - a Platform for Party Autonomy or the Privatization of Justice?’ (2016) https://www.city.ac.uk/_data/assets/word_doc/0010/336439/ADR-Party-Autonomyor-the-Privatization-of-Justice.docx accessed 10 December 2019.

38 Jeremy Waldron, 'The Rule of Law and the Importance of Procedure', in James E Fleming (ed), Getting to the Rule of Law (New York UP 2011).

39 The Chief Justice Sundaresh Menon (n 29) 16. In the same context, Trevor C. W. Farrow arguing for increased transparency and accountability in current dispute resolution mechanisms writes: 'Where a democracy deficit comes into play, however, is not in open court with "activist" judges, but rather when the important societal ordering tool of adjudication goes underground to private arenas, without 
By the same token, another critical argument is the lack of formal procedure in ADR and its replacement by flexibility and party-determined processes. It is well known that in ADR mechanisms there is often significant flexibility, so the parties can have notable control over what to agree on in regard to which procedure to follow, in order to resolve the dispute. Many legal scholars have raised questions about the use of such processes referring to a number of valid concerns about the lack of procedural safeguards in informal justice procedures. From the legal scholar's perspective such procedures may not be 'just'. For example, speaking about mediation as ADR method, Genn puts emphasis on the aspect of increased power of strong over weak. She writes:

'Precisely because it is an informal and consensual process, it can be used as an inexpensive and expedient adjunct to formal legal processes, seeming to increase access to justice, whereas in fact it can magnify power imbalances and open the door to coercion and manipulation by the stronger party. ${ }^{40}$

Finally, one additional concern has to be mentioned. It derives directly from private and entrepreneurial nature of ADR itself and defines the providers of the private justice. ${ }^{41}$ They have already been labelled as the 'private industry of dispute resolution' ${ }^{42}$ It is claimed that apparently their activities are subject to economic influences and thus inconsistent with the standards of impartiality and independence associated with the public justice and the Rule of Law.

Last, but not least, it's important to stress that the fair treatment of disputants in ADR processes seems to be the least criticized. It is suggested that ADR has enormous potential for accomplishing the needs of fairness and procedural justice of individual disputants. ${ }^{43}$ Parties' preferences for particular types of ADR are actually driven by procedural justice assessments, due to the fairness of these processes compared to litigation. In the same light, it is concluded that 'to the extent that this is true, and that parties want to engage in ADR because it appears more procedurally fair to them than traditional judicial decision making, the procedural justice parties experience in these processes may be a key facet of making these processes legitimate.' ${ }^{44}$

\section{CONCLUDING REMARKS}

The previous elaboration has been pretty much a quick review of the debates on one very intriguing topic in the modern system of dispute resolution. Of course, it is not

the guarantee of the rule of law badges of procedural fairness, transparency and independence of the decision maker. When decisions are made in these private circumstances, we often do not know what they are. And in any event, to the extent that we do know (which knowledge brings the broader behavior modification element of adjudication into play) we typically have no record or guarantee of the fairness of the procedural or substantive legal regimes that were employed to reach a given result.' Farrow (n 28) 16.

40 Genn (n 3) 90. Similarly, Trevor C. W. Farrow writes: 'There is a real danger that parties, particularly those with power, will increasingly use this privatizing system in order to circumvent public policies, accountability and notions of basic procedural fairness', Farrow (n 28) 16.

41 Murray (n 8) 144, who in this regard speaks about the dark side of privatized civil justice.

42 Ibid, 145.

43 See extensively Sternlight (n 22).

44 Rebecca Hollander-Blumoff \& Tom R Tyler, 'Procedural Justice and the Rule of Law: Fostering Legitimacy in Alternative Dispute Resolution' (2011) Journal of Dispute Resolution 13. 
enough to reflect the variety of thoughts that exist in an extensive and rich literature on the issue, but somehow to highlight the thoughts that we find the most salient. Having in mind the points of the literature reviewed, but also the author's personal professional background ${ }^{45}$ we would like to share very briefly our own observations and to give an answer to the titled question.

Our first point is that ADR and the Rule of Law may actually be mutually supportive rather than mutually exclusive. Although aware that this point of view may have disagreements, the underpinnings of our opinion are as follows. When the judiciary or the public justice system does not meet societal needs, it is to be expected that citizens and businesses will resort to and rely on alternative mechanisms offered to them. Or to put it differently: if the Rule of Law is important for social and economic development while public justice institutions are performing badly and more and more citizens and businesses rely on informal alternatives, it seems necessary to consider these alternatives along with the formal public justice institutions in development strategies relating to the Rule of Law. ${ }^{46}$ This implies that the Rule of Law is not in tension with ADR mechanisms because at the end of the day they both aim to achieve the same goals - to resolve the disputes and the pursuit of justice. In this context, justice itself should be considered as a wider concept than the adjudication of legal rights and wrongs.

The second point we want to stress and which seems to us undisputable is the fact that the virtues of the Rule of Law mentioned previously are neither perfectly compatible with ADR, nor entirely incompatible with it. This might be a topic for long and neverending discussions with a plenty of pros and cons. However, it seems worthless to debate about it, although the rise of private justice system will further raise questions of transparency, legitimacy, accountability etc. In our opinion what is more important is the fact that as soon as ADR mechanisms can help maintain societal values that are consistent with the Rule of Law (such as equality and fairness), we can claim nothing else but that the ADR is promoting the Rule of Law. And we think it should be accepted even when ADR mechanisms do not produce outcomes that arise directly from the Rule of Law by definition, but are rather based on interests and preferences of the parties.

Thus, our further, and from our perspective the most important point is to ensure that the complementary ADR mechanisms meet the minimum procedural standards of the Rule of Law concept. To be more precise: when the disputants' individual perception is that the outcome of the ADR derives from the equal and fair treatment they get, they will highly prize ADR and certainly will choose it in the future. No matter how private

45 The author has spent nearly 25 years researching and teaching civil procedure. Recently the author has been involved in ADR mechanisms, predominantly in arbitration, both academically and practically. So, having devoted most of her working life to public justice system, the author also experienced the privatized one. Therefore, the author's observations are not merely theoretical, but somehow empirical as well.

Similarly, Bryant G. Garth speaking about the relation between the public and private justice system says: 'From one perspective, the two systems are no longer discrete conversants but have begun to be "integrated", "melded" or "collapsed" into each other. From another vantage point, the state's system is increasingly in disarray, and the "private" system is becoming the one of choice, when litigants have the resources and ability to "opt out". Bryant G Garth, "Privatization and the New Market for Disputes: A Framework for Analysis and a Preliminary Assessment' (1992) 12 Studies in Law, Politics, and Society 374. 
and confidential it is. The very essence of the matter will be whether individuals and businesses have confidence in ADR mechanisms, because that confidence is fostering the legitimacy of ADR.

This leads us to the last point we want to make. It covers the professional standards to which all private justice providers should adhere to. Only the highest professional standards will promote and sustain the quality of private justice services, strengthening public trust and confidence in them. Just like the independence and impartiality standards do the same for the judiciary.

Finally, having in mind all that was previously presented and keeping the very spirit of this event, celebrating the European day of justice, we will conclude: privatization of civil justice is not only an issue of promoting the access to justice, but also an issue of promoting a positive perception of the justice system overall. Namely, the practice and various studies show that individuals and businesses using ADR mechanisms generally report high levels of satisfaction and therefore attribute that satisfaction to the judicial system taken as a whole. This suggested that ADR does not jeopardize the fundamental values of the civil justice system, but contributes in creating the positive image of it. 